\title{
The Politics of Amnesty in Nigeria: A Comparative Analysis of the Boko Haram and Niger Delta Insurgencies
}

\author{
by Michael Nwankpa
}

\section{(cc) Br}

This work is licensed under a Creative Commons Attribution 3.0 License.

\section{Introduction}

his paper presents a comparative analysis of the Niger Delta amnesty programme and the proposed amnesty for Boko Haram insurgents in Nigeria. The motivation for comparing the two groups derives from the growing demand from some notable groups and individuals, mainly from the northern part of Nigeria, that the Boko Haram insurgents be granted amnesty just as the Niger Delta armed militants. One of such strong voices in favour of amnesty for Boko Haram insurgents is the Sultan of Sokoto, AlhajiSaadAbubakar, who, on the 7th of March 2013, called for "total and unconditional" amnesty for Boko Haram. Sultan Abubakar's demand has attracted mixed reaction as it is largely supported by the northern group-Arewa Consultative Forum (ACF) and rejected by others such as the Christian Association of Nigeria (CAN). The most serious reaction comes from the presidency in its commission, on April 24th 2013, of a presidential Committee on Dialogue and Peaceful Resolution of Security Challenges in the North. After an extension by 2 months of its initial 90 days task, the Turaki-led Committee on Dialogue and Peaceful Resolution of Security Challenges in the North has finally submitted its recommendations to the president. Two key recommendations are: the need to set up an advisory committee for continuous dialogue with Boko Haram (as the leadership of Boko Haram refused to dialogue) and a victims' support fund to help victims of Boko Haram.

The idea of granting amnesty to Boko Haram has been justified against the background of amnesty granted to the Niger Delta militants from 2009-2010. In his account, Okpi (as cited in Sampson, 2013) argues that:

If the Niger-Delta militants could be granted amnesty despite the wanton destruction of oil facilities and indiscriminate killings of innocent citizens...then an olive branch should equally be extended to Boko Haram. They are both militant groups with destructive tendencies...so, what is good for the goose is also good for the gander (p. 19)

It is therefore necessary to evaluate the logic behind the audacious statement above. The main concern of this paper therefore is to evaluate the Niger Delta amnesty programme as a suitable model for the proposed amnesty for Boko Haram. Sampson (2013) is the only study that has to a great extent attempted to compare the Niger Delta amnesty and the proposed Boko Haram amnesty. This is quite understandable, as the proposal for dialogue and peaceful resolution for the Boko Haram conflict, although not new (Johnson, 2011), has just gained momentum in the past few months, as manifested in the inauguration of the Committee on Dialogue and Peaceful Resolution of Security Challenges in the North. This paper is divided into 3 parts: a brief background on Niger Delta and Boko Haram, a discussion of the legitimacy of amnesty, and the comparison between Niger Delta amnesty programme and the proposed Boko Haram's amnesty. 


\section{Journal of Terrorism Research}

\section{Niger Delta: A Brief History}

The Niger Delta struggle is motivated by the demand for resource control and equitable wealth distribution and protest against the flagrant and damaging (ecological) activities of oil multinational companies (MNCs) operating in the region (Ikelegbe, 2005; Obi, 2010; Oluwaniyi, 2011; Sampson, 2013). According to Ikelegbe (2005) "decades of oil exploitation, environmental degradation and state neglect has created an impoverished, marginalised and exploited citizenry (leading to) a resistance of which the youth has been a vanguard" ( $\mathrm{p}$. 208). The Niger Delta struggle predates the discovery of oil and political independence (Sampson, 2013; Oluwaniyi, 2011). However, its non-violent protest has transformed into what Ikelegbe (2005) describes as

a region of intense hostilities, violent confrontations and criminal violence...pervaded by a proliferation of arms and institutions and agencies of violence ranging from the Nigerian Armed Forces to community, ethnic and youth militias, armed gangs and networks, pirates, cultists and robbers ( $p$. 208-209).

In response, the Nigerian government has largely favoured the use of force, as carried out mostly by the nation's Joint Task Force (JTF) (Ojakorotu\& Gilbert, 2010; Tessier, 2009). There is evidence also of nonviolent counterterrorism (CT) approaches as would be represented by several government development policies. The Niger Delta Development Board (NDDB) established in 1961 by the Niger Delta Development Act, the Oil and Mineral Producing Area Development Commission (OMPADEC) created by Decree 23 of 1992, the Niger Delta Development Commission (NDDC) set up in 2000, and the Ministry of Niger Delta formed in 2008, are some examples of the development approach adopted by the Nigerian government in countering the insurgency. The 2009 amnesty is the latest of such development strategy.

\section{Boko Haram: A Brief Introduction}

Since 2009, Boko Haram has gained relevance as a notorious insurgent group. Its notoriety is internationally recognised as it has been proscribed by the United Kingdom and blacklisted as a terrorist organisation by the United States. Boko Haram whose original name is Jama'atuAhlisSunnaLidda'awatiWal-Jihad ("People Committed to the Propagation of the Prophet's Teachings and Jihad”) has carried out a campaign of attacks on symbols of authority such as the police and military. Police stations, military barracks and other government buildings and establishments as well as media houses and international organisations (attack on the United Nation's building in the nation's capital-Abuja) have been attacked. There have also been sustained attacks on Christians and their places of worship, market places and other public places. Suicide attacks, bombings, assassinations, and recently, kidnapping of foreign nationals, feature as some of their methods of attack. It is worth noting most of its attacks are confined to the Northern states (mainly northeast states such as Borno, Adamawa, and Yobe), including Kano, Kaduna and Sokoto.However, Boko Haram has unsuccessfully attempted in the past to expand its reach to Southern states such as Lagos. Even in high risk zones such as the capital of Borno, Maiduguri, the assault of the JTF on the sect has constrained Boko Haram's attacks to villages and towns outside Maiduguri.

While it is widely acclaimed that Boko Haram was formed in 2002 by a radical Islamist cleric known as Mohammed Yusuf, some commentators argue that the group has been in operation before 2002 and has operated under different names such as the Nigerian Taliban, and Yusufiyya (Adesoji, 2011). However, one tie of historical relevance that has gained recognition among scholars and critics interested in the Boko Haram insurgency is its link to the Maitatsine Riot of the early 1980s [1980-1985] (Johnson, 2011; Waldek\&Jayasekara 2011). Boko Haram bears strong resemblance to the Maitatsine riots of the 80s in 
its vitriolic criticisms and attacks on the Nigerian state (including the police and military) and perceived moderate/ambivalent Muslim clerics, and level of damage (about 5000 people died between 1980-1985 even after Mohammed Marwa or "Maitatsine"-“The one who damns" was killed in 1980) (Adesoji, 2011). There is also very little difference between the socio-economic conditions that facilitated the emergence of Maitatsine and Boko Haram (Adesoji, 2010).

The motive behind Boko Haram's violent activities is one that is difficult to identify. Alozieuwa (2012) provides five different theories that explain the motivation for Boko Haram- human needs/socio-economic; political feud, Islamic Theocratic State, conspiracy theories, and relational vengeance theory perspectives (see also Anyadike, 2013).The main objective, as claimed by Boko Haram is to transform the Nigerian state into an Islamic nation. However, Boko Haram'sreligious explanation of its act of violence (as with most religiously-motivated groups) has been challenged as having no basis in Islam, especially its intolerance of people of other religions (Achtar, 2010). The uncertainty of Boko Haram's motive has made it difficult to counter the terror that it poses.

The Nigerian government has responded strongly to the threat posed by Boko Haram by favouring a strong military counter-terrorist strategy carried out by the JTF. Other non-military counter-terrorist approaches include the use of counter-narratives and, of particular relevance to this paper, the commissioning of a committee to advise on dialogue with Boko Haram insurgents, with possible amnesty granted to the group.

\section{Amnesty: The Question of Legitimacy}

One argument that has dominated the literature on amnesty is the question of legitimacy (Slye, 2002; Heine, 2007; Sadat, 2007; Scharf, 2007; Laplante, 2012). Amnesty has long been a political tool used by governments for both good and bad purposes. It is a tractable political tool that lends itself to wide-ranging purposes, some of which are morally right and some that are self-serving (Slye, 2002). Slye (2002) argues further that amnesties "have been granted at times of great social stability and at times of great social unrest" (p. 174). We may therefore scrutinise amnesties from the basis of their intentions or morality. However, the most scrutiny of amnesty comes from the domain of law, especially international law.

Following the end of World War Two, we see a rise in international frameworks such as the United Nations with several promulgations of international conventions, treaties, and laws that govern human relations at international, regional and state levels and forestall the kind of atrocities that were displayed during the war. It is within this framework that we recognise the Universal Declaration of Human Rights (UDHR) in 1948, Geneva Convention in 1949, among a host of other conventions and multilateral treaties. There are also a reasonable number of international courts such as Inter-American Court, International Criminal Court (ICC), and several Human Rights Commissions. These international mechanisms have been used to correct grave human rights violation of the past and poised with growing legal force to address any potential human rights violations. It is within the purview of human rights that the legitimacy of amnesties is questioned.

In spite of these international agencies and human rights structures, there seems to be a surge in amnesties. Slye (2002) posits that the rise in the use of amnesties is "less a reflection of our increased tolerance of impunity and more of an indicator of the growing force of the international human rights movement and international criminal law" (p. 175). The increasing use of amnesties by states can actually enhance human rights when they are done in good faith and with the utmost consideration given to truth and accountability, but, when they are used deliberately to prevent justice, their legitimacy becomes questionable.Such is the case with the amnesties of Argentina and Chile. The subsequent repeal of the "Full Stop" law and other amnesty 


\section{Journal of Terrorism Research}

laws by President Alfonsin to halt the trials and prosecution of military officers and the trial of Pinochet and reopening of cases of human rights violation against the Chilean military through both national and international courts establish the case for retributive justice.

However, the former President of ICC Phillippe Kirsch says that "some limited amnesties may be compatible with a country's obligation genuinely to investigate or prosecute under the Statute" (cited in Dworkin, 2003). But the apparent absence of a clear and definable restriction on amnesties in international law frameworks pose a serious problem for the legality of such mechanisms used by states in the process of national reconciliation. The extent to which a state can go in the use of amnesty is not explicitly defined in ICC. While there is an implicit consensus between states and international legal bodies of certain non-derogable rights such as represented by the Geneva Convention, and crimes of genocide, virtually all international legal frameworks are unclear about crimes against humanity and other war crimes (Heine, 2007; Scharf, 2007; Slye, 2002). Hence, state amnesties do not protect individuals and groups that have committed gross human rights violation of international standard from international prosecution, as the Chilean and Argentine postamnesty trials and the trial of Liberian Charles Taylor in the International Criminal Court prove.

This attempt at differentiating national and international-level crime nonetheless fails to conceal the conflict between domestic and international laws and tribunals in relation to the legality of amnesty (Sadat, 2007; Scharf, 2007; Slye, 2002). States are required under international law to prosecute gross violators of human rights; protect the fundamental rights of victims, and "establish a stable democracy that honours human rights and the rule of law" (Slye, 2002, p.182). Amnesties violate these international laws, according to their critics. The sympathisers of amnesties have often claimed that amnesties guarantee peace, truth and reconciliation. Slye (2002) discusses these three goals within "the rule of law", "victim's rights", and "obligation to prosecute" arguments (p. 182). He finds, inhibitive to prosecutorial discretion, a strict adherence to international requirement to prosecute. A state may be limited by resources and capacity to pursue full prosecution, hence may be selective in the crimes it prosecutes. Also, there are other "non-prosecutorial means to further the legitimate goals of a criminal justice system" (Slye, 2002, p. 184). More so, as restorative justice argument espouses, punishment is not the only form of criminal justice. Criminal justice can gain accountability within the framework of Truth Commissions. However, the restorative justice school of thought rejects blanket amnesties. The challenge for proponents of restorative justice, as Slye (2002) argues is to find the "methods of accountability that de-emphasise punishment" (p. 187; Naqvi, 2012; Laplante, 2012; Heine, 2007).

From the perspectives of fundamental human rights of victims, amnesties are criticised on the grounds that they violate five crucial principles- right to justice, right to truth, right to judicial protection, right to reparations, and, right to access to court (Slye, 2002, p. 191). Amnesties are also viewed as providing shortlived social stability, and are inimical to the long-term enjoyment of a stable democracy, human rights and rule of law. Sadat (2007) describes amnesties as having "little moral or persuasive force" (p. 240), and Slye (2002), using the examples of the amnesties given by the governments of Argentina and Chile, posits that "short-term amnesty eventually gives way to individual accountability" (p. 200). Amnesties, as can be deduced, are not undesirable. They can gain enhanced legitimacy if they fulfil certain conditions: strive for accountability and truth, and guarantee reparations and participation.

\section{The Niger Delta Amnesty: A True Model?}

On $25^{\text {th }}$ June 2009, the late former President of the Federal Republic of Nigeria, Musa Yar'Adua, in exercising his constitutional power under Section 175 of the constitution of the Federal Republic of Nigeria, 


\section{Journal of Terrorism Research}

granted amnesty and unconditional pardon to the Niger Delta militants. The pardon was effective for a period of 60 days (25th June-4th October, 2009), requiring the militants to surrender every weapon and ammunition in their possession and to publicly denounce militancy.With constant increase in oil production and consequently increase in oil revenue, and a significant reduction in violence in the region, many commentators have described the amnesty programme in glowing terms. Interestingly, supporters of amnesty for the Boko Haram insurgent group have referenced the Niger Delta amnesty. It becomes therefore crucial to evaluate the implication of this connection between the Niger Delta and Boko Haram, especially in the light of perceived differences in their motivations.

The Niger Delta conflict, for several decades, was sustained by a socio-economic drive. This, as stated earlier, includes resource control, equitable wealth distribution and protest against the environmentally-damaging activities of the oil MNCs. This obviously appears different from the self-acclaimed motivation by Boko Haram to transform Nigeria into an Islamic state. The comparison of the proposed Boko Haram amnesty with the Niger Delta amnesty seems insensitive to the plight of the victims and ignorant of growing evidence that group ideology and motivation are crucial to an effective counterterrorism (CT) measure (Miller, 2007; Forest, 2009; Crenshaw, 2007; Sederberg, 1995; Abrahms, 2008). Arguably, the demand for amnesty for the Boko Haram insurgents comes short of an attempt at political correctness, and, significantly, reveals a Nigerian State that is politically divided along ethnic and religious lines and biases.

The argument put forward by supporters of amnesty for the Boko Haram insurgents fails to conceal the divisive tendencies within the ethnic and religious composition of Nigeria that play out in its political space (Fayemi, 2003). The argument of "what is good for the goose is also good for the gander" undermines the rule of law, victim's right and the state's duty to prosecute (Slye, 2002). More so, the Niger Delta amnesty programme may not after all be a correct model for the proposed Boko Haram amnesty.

The Niger Delta amnesty programme has been hailed by local and international commentators as largely successful. It is tempting to accept this popular view, especially when we compare the relative peace in the Niger Delta region to the incessant violent attacks and militancy from 2000 to 2009. Since 2009, relative peace has returned to the region and there is an increase in the production of oil (from 700,000 barrels per day to between 2.4 million and 2.6 million barrels per day) and, consequently, increase in the generation of oil revenue (Jamestown Foundation, 2013; Alike, 2013). The federal government recovered arms from the militants who surrendered and renounced violence during the first stage of the amnesty programme-disarmament and demobilisation. The militants surrendered in return for formal education and vocational skills training and monthly stipends for a period of 5 years. This explains the second phase of the programme-rehabilitation and reintegration. Mr Kingsley Kuku, the chairman of the Presidential amnesty programme argues that over 16,000 out of the over 30,000 enrolled Niger Delta youths have received training in different fields within and outside Nigeria (Jegede, 2013).

There is no doubt that the Niger Delta amnesty programme presents some great merits. What is rather doubtful is whether the militants surrendered all the arms in their possession, as is the case with most armed insurgents, and especially evident in the rising violence in the region and the growing threat from militants' chiefs (Muggah\&Batchelor, 2002; Gilbert, 2010). Hence, we may not have seen the end of violence in the Niger Delta region, as there is an increase in piracy in the region and other violent incidents that are largely unreported. In 2013 alone, out of about 34 piracy attacks in the Gulf of Guinea, 30 are related to Nigeria, with " 29 piracy incidents, including two hijackings, 11 ships boarded, 13 vessels fired upon and three attempted attacks" (Anaesoronye, 2013; International Chamber of Commerce, ICC, 2013). Also, on the 24th of October 2013, Niger Delta pirates attacked a United States (US) vessel and kidnapped two US nationals. 


\section{Journal of Terrorism Research}

The abducted US nationals were released on the 12th of November 2013, but details of the terms of their release are undisclosed. Another evidence of the rise of violence in the region is the October 22ndexplosion in an oil refinery in Warri-an action that the Movement for the Emancipation of Niger Delta (MEND) claims responsibility.

It is also worrisome that pipeline attacks (oil theft) is on the increase and about 20 per cent $(400,000$ barrels per day) of the country's fuel production is lost to oil thefts (Reuters, as cited by Jamestown Foundation, 2013). The Nigerian government loses about $\$ 7$ billion yearly to oil pipeline attacks, and loses a further $\$ 5$ billion to the repair of the pipelines (Jamestown Foundation, 2013)

We may otherwise say that the Niger Delta amnesty, like the Northern Ireland peace process needs time to solidify. As is the case in Northern Ireland, the peace process was stalled by intermittent violence between the first ceasefire in 1994 and 2005 when the warring groups finally put down their arms beyond use. Therefore, "the failure to resolve the arms issue" contributed largely to the stalling transitional peace process in Northern Ireland (Monaghan, 2008, p.85). It is therefore not surprising that setting penalties for the use of violence was one of the three factors that ensured the success of the Northern Ireland Peace process. The other two are the adoption of an inclusive process (involving main spoilers in the peace process) and the lack of direct economic motivation (such as the presence of a natural/primary resource) (MacGinty, 2006).

While the resolution of the Northern Ireland conflict may provide useful lessons to the Niger Delta and Boko Haram peace processes, certain conditions make themselves distinct in the case of the Nigerian conflicts. The political-economy of the Niger Delta conflict is higher than that of Northern Ireland as there is primary resource (oil) in the Niger Delta. Hence, economic (direct) motivation defines the Niger Delta conflict. However, economic motivation in the Niger Delta crisis is dependent, as there was and still is a genuine demand for economic improvement of the region. It becomes difficult therefore to separate the ongoing violence from the continuing poor development and environmental despoliation of the Niger Delta region. The Niger Delta amnesty programme- disarmament, demobilisation, and rehabilitation, has been criticised on many grounds- it is not clear on the role of oil MNCs (Adeyemi\&Olu-Adeyemi, 2010), it does not provide justice to victims (Ubhenin, 2013), there is lack of accountability in its drafting and implementation (Ubhenin, 2013; Muggah\&Batchelor, 2002), it is given in a vacuum (Samson, 2013; Gilbert, 2010), and it is too militant-centred (Ubhenin, 2013).

The major criticism however comes from its failure to address the basic socio-economic and environmental needs in the region (Oluwaniyi, 2011). The Niger Delta amnesty, as such, may not be different from past amnesties such as the one General Gowon offered Isaac Boro (a Niger Delta revolutionist that raised a mutiny against the Federal Government of Nigeria for 12 days in 1967) and the Biafran war lords during and after the Nigeria-Biafra Civil War (1967-1970) or the many presidential pardons granted to political prisoners since independence. The failure to address the fundamental needs of the Niger Delta people could potentially undermine the adjudged success of the Niger Delta amnesty programme. It is pertinent to add here that the huge pay-out given to the militants may be the incentive for their perceived voluntary surrender of arms. Significantly, since the declaration of Niger Delta amnesty, the Ministry of Niger Delta Affairs has received a total of $\nabla 181$ bn (2009-2011), and the budget for Niger Delta amnesty for 2012 alone is $\$ 450 \mathrm{~m}$ (Ubhenin, 2013 , p. 80). It is very likely that the "repentant" militants can divert the money to buying more arms, as the money is supposedly spent on feeding and reintegrating the ex-militants. Recent threats from the leaders of the Niger Delta militants suggest that such is possible, and that the militants may not have surrendered all their arms. The federal government is therefore in the right course in its recent inauguration of the Committee on Small Arms and Light Weapons (April 24th, 2013). While this move would help mitigate the 


\section{Journal of Terrorism Research}

proliferation of arms, it coincides with the recent international embargo on the sales and distribution of small arms.

\section{Boko Haram Amnesty: Right or Wrong?}

Considering the evidence put forward concerning the Niger Delta amnesty programme and previous amnesties in Nigeria, the motion for amnesty for the Boko Haram sect may be ill-advised. Such a narrow proposal straitjackets a comprehensive understanding of the group's motivation, as well as forecloses other viable and effective CT measures. Interestingly, there is no standard CT approach (Miller, 2007). In the absence of a unified and comprehensive CT theory, flexibility and adaptability in CT policies become necessary (Crenshaw, 2007; Miller, 2007). The best CT approach to the Boko Haram insurgency would be one that is considered based on a careful study and clear understanding of the perceptions, associations and scope of its network. The lack of a unified explanation for the Boko Haram insurgency and the many conspiracy theories add to the ineffectiveness of the CT measures used so far. The Nigerian government should therefore work towards achieving a true assessment of the Boko Haram conflict. This should be the task of the Committee on Dialogue and Peaceful Resolution of Security Challenges in the North. The Committee should not be fazed by the chant for amnesty for Boko Haram.

Interestingly, while the stick and carrot approach by the Jonathan administration towards Boko Haram have failed to make a lasting impact, one needs to appreciate the administration's openness to different approaches, including dialogue and peaceful resolution of the crisis as embodied by the Turaki-led Committee.

Conciliation and negotiation are very powerful tools for mitigating terrorism (Malvesti, 2002; Sederberg, 1995). These soft approaches to CT are fast gaining grounds, as hard power approaches such as the use of drones and airstrikes have come under intense criticisms as they do not only tend towards collateral damage, but fail to overcome terrorism. There is growing consensus that they even escalate violence and strengthen rather than weaken the resolves of terrorists groups. The Niger Delta insurgency is one clear example of a conflict that degenerated from a non-violent protest to a militant one as a result of the government's hard military offensive.

The unpopularity of drones and airstrikes does not however justify blanket amnesty to groups such as Boko Haram. As amnesties of the Latin American countries (particularly Chile andArgentina) prove, amnesties only provide short-term gains and are incompatible with ideals of justice and international laws (Grandin, 2005; Scharf, 2007; Slye, 2002; Sederberg, 1995; Malvesti, 2002; de Mesquita, 2005). This sounds true of the Niger Delta amnesty as its critics, including militants' chiefs, who are still benefitting from the programme, decry the programme as bribe. In the absence of true development of the region, lasting peace is only an illusion. Hence, the Niger Delta amnesty programme cannot be replicated in the North because the programme does not address the basic demands of the people of the Niger Delta, as Boko Haram's objectives do not reflect the views of the majority in the Northern region.

Such comparisons underscore the ethnic and religious sentiments that colour Nigeria's political space. The advocates of amnesty for Boko Haram based on amnesty for Niger Delta either fail to understand the cultural, economic and political differences between the Boko Haram and Niger Delta cases or they use amnesty as a manipulative instrument, as would be the case between Israel and Palestine peace process (Ranstorp, 2006). Boko Haram's amnesty will therefore be a "strategic art of deception" that shifts our focus away from the real problems (Ranstorp, 2010, p.242).This fact is substantiated by Boko Haram's rejection of the proposed amnesty and its past condemnation of supposed dialogue between the sect and the government. There is ample evidence to show that it is the moderate factions (and not the extremist faction) of insurgent 
groups that are most likely to accept government concessions (de Mesquita, 2005). This becomes even more potent in the case of Boko Haram.

Boko Haram's acclaimed religious motivation is different from the secular demands by the Niger Delta militants. Sederberg (1995), quoting Bruce Hoffman, argues that "religiously motivated challengers are more likely to view their struggle in totalistic terms...resist[ing] utilitarian calculations in their political decision-making, whereas secular motivation for increased autonomy within a political community offers greater promise for a conciliatory strategy of transformation" (p.308). Hence, while amnesty may have helped reduced violent conflict in the Niger Delta, the same may not likely happen, if Boko Haram is offered amnesty. It is however important to mention that while there are indeed differences between the two crises, there remains an underlying similarity in relation to socio-economic issues. Hence, socioeconomic interventions (through development of infrastructure, job creation and poverty alleviation) by the government, as well as improved governance and genuine fight against corruption may be very useful in addressing the Boko Haram crisis, particularly towards creating a disincentive for the largely impoverished youth to be recruited into the sect.However, the Niger Delta amnesty is largely flawed on the grounds of accountability. It has failed to address fundamental issues that are the basis for the conflict and, may be potentially damaging as reflected by the military force that has been largely used. The monetary incentives for the militant is a great disincentive towards a long-lasting solution to the conflict, and the increasing crimes in the region and growing threat from "repentant"militant chiefs are clear indicators. In the light of the proposed Boko Haram amnesty, it will be unwise to follow the same fruitless path as the Niger Delta amnesty.

\section{Conclusion}

It seems very difficult finding a delicate balance between restorative and retributive justice. As valid as the argument for national reconciliation and national unity (through amnesty) is, equally important, if not more important, is the need to prosecute violators of human rights. The South African Truth and Reconciliation Commission (TRC) is perhaps the only one, out of a number of amnesties around the world that comes closest to achieving this balance. Other amnesties and truth commissions such as the ones given in Chile and Argentina lend little support for unconditional amnesty. The prosecution of key perpetrators in the Chilean and Argentine persecution, arrest and torture of political opponents in the 1970s and 80s and the continuous search for justice by victims of these heinous crimes explain why amnesty may be unfit for a progressive criminal justice system. Although amnesty is not altogether undesirable, its gains are rather temporary and conflict with justice and human rights ideals.

It becomes therefore imperative to carefully consider the proposition of amnesty for Boko Haram insurgents, especially against the not-too-impressive amnesties in the continent and the country. Past amnesties and pardons in Nigeria have failed to build a strong national consciousness in Nigeria. Virtually, every geopolitical and ethnic group in Nigeria express one form of discontentment or another. In the South East, the Igbos feel marginalised due to the failure of successive Nigerian governments to develop the region, despite the amnesty offered to Biafran warlords by Gowon (Amadi, 2007). The same trend is observable in the Niger Delta case where critics of the Niger Delta amnesty programme (including beneficiaries) criticise the Federal government for its failure to address the basic concerns in the region.

Therefore, understanding motivations for grievances and addressing them will seem a wise thing to do. Such motivations that are applicable to the Niger Delta and Boko Haram insurgencies include "perceptions of social exclusion, real or perceived discrimination, frustrated expectations, and government repression [that] may push individuals into collective violence" (Aldrich, 2012, p. 48). Arguably the assumption: what is good 
for the goose is also good for the gander does not hold sway, as the "goose" in this case; the Niger Delta amnesty presents a fundamentally flawed model for the proposed Boko Haram amnesty.

About the author: Michael Nwankpa is a PhD candidate in the University of Roehampton, London. He is an expert on counter-terrorism and counter-insurgency in Africa. He is presently working on the dilemma of security,development and human rights, with special focus on the Boko Haram and Niger Delta Conflicts in Nigeria. (mnwankpa@gmail.com)

\section{References}

Abrahms, M. (2008). What terrorists really want: Terrorist motives and counterterrorism strategies. International Security, 32(4), 78-105.

Achtar, A. (2010). Challenging Al-Qa'ida's justification of terror. In Fisher, D., \& Wicker, B (Eds.), Just War on Terror: A Christian and Muslim Response (pp.25-36).Surrey: Ashgate Publishing Limited.

Adesoji, A. (2010). The Boko Haram uprising and Islamic revivalism in Nigeria.Afrika Spectrum: Deutsche ZeitschriftFürGegenwartsbezogeneAfrikaforschung, 45(2), 95.

Adesoji, A.O. (2011). Between Maitatsine and Boko Haram: Islamic fundamentalism and the response of the Nigerian state.Africa Today, 57(4), 98-119.

Adeyemo, D., \& Olu-Adeyemi, L. (2010). Amnesty in a vacuum: The unending insurgency in the Niger Delta of Nigeria. InOjakorotu, V., \& Gilbert, L. D (Eds.),Checkmating the Resurgence of Oil Violence in the Niger Delta of Nigeria(pp. 24-46). Retrieved from http://www.iaags.org/Niger Delta book.Pdf.

Aldrich, D.P. (2012). Mightier than the sword: Social science and development in countering violent extremism.In Shaw, R., \&Radelet, S (Eds.), Frontiers in Development (pp. 46-50). Washington: United States Agency for International Development.

Alike, E. (2013, July 23). Nigeria produces 2.5mbpd of crude oil. ThisDay.Retrieved January 8, 2014 from http://www.thisdaylive.com/articles/nigeria-produces-2-5mbpd-of-crude-oil/154098/.

Alozieuwa, S.H. (2012).Contending theories on Nigeria's security challenge in the era of Boko Haram insurgency.Peace and Conflict Review, 7(1), 1-8.

Amadi, S. (2007).Colonial legacy, elite dissension and the making of genocide: The story of Biafra. Retrieved November 20, 2013 from http://howgenocidesend.ssrc.org/.

Anaesoronye, M. (2013, October 23). Nigeria in global picture for growing marine risks.BusinessDay.

Retrieved from http://businessdayonline.com/2013/10/nigeria-in-global-picture-for-growing-marine-risks/.

Anyadike, N. O. (2013). Boko Haram and national security challenges in Nigeria; causes and solutions.

Journal of Economics and Sustainable Development, 4(5), 12-23.

Crenshaw, M. (2007).The organization of terrorism. In Ellis, J.O(Ed.),Terrorism: What's Coming The Mutating Threat (pp.19-27). Oklahoma: Memorial Institutefor the Prevention of Terrorism (MIPT).

deMesquita, E.B. (2005).Conciliation, counterterrorism, and patterns of terrorist violence.International Organization, 59, 145-176.

Dworkin, A. (2003). Introduction. In The International Criminal Court: An End to Impunity? Retrieved from http: www.crimesofwar.org (Crimes of War Project). 


\section{Journal of Terrorism Research}

Fayemi, K. (2003). Governing the security sector in ademocratising polity, Nigeria. In Cawthra, G., \& Luckham, R (Eds.), Governing Insecurity: Democratic Control of Military and Security Establishment in Transitional Democracies (pp. 57-77). London \& New York: Zed Books

Forest, J. J. (2009, January). Terrorism as a product of choices and perceptions. Paper presented in CATO Institute Conference on "Shaping the New Administration's Counterterrorism Strategy," Retrieved from http:// www.jamesforest.com/wp-content/uploads/2010/05/Forest-CATO-Essay-Jan-091.pdf/.

Gilbert, L.D. (2010). Youth militancy, amnesty and security in the Niger Delta region of Nigeria.In Ojakorotu, V., \& Gilbert, L. D (Eds.), Checkmating the Resurgence of Oil Violence in the Niger Delta of Nigeria(pp. 47-66). Retrieved from http://www.iaags.org/Niger Delta book.Pdf.

Grandin, G. (2005). The instruction of great catastrophe: Truth commissions, national history, and state formation in Argentina, Chile, and Guatemala. The American Historical Review, 110(1), 46-67. Retrieved from http://www.jstor.org/stable/10.1086/531121.

Heine, J. (2007). All the truth but only some justice?Dilemmas of dealing with the past in new democracies. In Schabas, W.A., Hughes, E., \& Thakur, R.C (Eds.),Atrocities and international accountability: Beyond transnational justice(pp. 65-80).Tokyo, Japan: United Nations University Press.

Ikelegbe, A. (2005). The economy of conflict in the oil rich Niger Delta region of Nigeria. Nordic Journal of African Studies, 14(2), 208-234.

International Chamber of Commerce. (2013, October 22). Piracy and armed robbery news and figures. Retrieved November 19 from http://www.icc-ccs.org/piracy-reporting-centre/piracynewsafigures/.

Jamestown Foundation. (2013, March 8). No end in sight: Violence in the Niger Delta and Gulf of Guinea. Terrorism Monitor, Retrieved November 3 from http://www.refworld.org/docid/513d9cd02.html/.

Jegede, M. (2013, November 5). Nigeria: Tinubu's onslaught on Niger Delta amnesty. ThisDay.Retrieved November 19 from http://allafrica.com/stories/201311050890.html?viewall=1/.

Johnson, T. (2011).BokoHaram.Backgrounder.Retrieved November 11 from http://www.cfr.org/nigeria/bokoharam/p25739/.

Laplante, L. J. (2012). Outlawing amnesty: The return of criminal justice in transitional justice schemes*. RevistaEspaçoJurídico| EspaçoJurídico Journal of Law [EJJL], 13(3), 59-116.

MacGinty, R. (2006). Northern Ireland: A peace process thwarted by accidental spoiling. In Newman E., Richmond O. P. (Eds.), Challenges to peacebuilding : Managing spoilers during conflict resolution (pp. 153-172). Tokyo, Japan: United Nations University Press.

Malvesti, L.M. (2002). Bombing bin Laden: Assessing the effectiveness of air strikes as a counter-terrorism strategy. The Fletcher Forum of World Affairs, 26(1), 17-29.

Miller, G. D. (2007). Confronting terrorisms: Group motivation and successful state policies. Terrorism and Political Violence, 19(3), 331-350.

Monaghan, R. (2008). Community based justice in Northern Ireland and South Africa. International Criminal Justice Review, 18(1), 83-105.

Muggah, R.,\&Batchelor, P. (2002). Development held hostage: Assessing the effects of small arms on human development- A preliminary study of the socio-economic impacts and development linkages of small arms proliferation, availability and use. New York: The United Nations Development Programme.

Naqvi, Y. (2006). The right to the truth in international law: Fact or fiction? International Review-Red Cross- 


\section{Journal of Terrorism Research}

New Series-, 88(862), 245-273.

Obi, C. I. (2010).Oil extraction, dispossession, resistance, and conflict in Nigeria's oil-rich Niger Delta.

Canadian Journal of Development Studies/Revue Canadienned'Études Du Développement, 30(1-2), 219-236.

Ojakorotu, V., \& Gilbert, L.D. (2010). Understanding the context of oil violence in the Niger Delta of Nigeria, Chapter 1, in Checkmating the Resurgence of Oil Violence in The Niger Delta of Nigeria, Ojakorotu, V., and Gilbert, L.D. (Eds.), Retrieved from http://www.iaags.org/Niger Delta book.Pdf.

Oluwaniyi, O. O. (2011). Post-Amnesty programme in the Niger Delta: Challenges and prospects. Conflict Trends, 4, 46-54.

Ranstorp, M. (2006). The Israeli-Palestinian peace process: The strategic art of deception. In Newman E., Richmond O. P. (Eds.), Challenges to peacebuilding: Managing spoilers during conflict resolution (pp. 242-261). Tokyo, Japan: United Nations University Press.

Sadat, L.N. (2007). The effect of amnesties before domestic and international tribunals: Morality, law and politics.In Schabas, W.A., Hughes, E., \& Thakur, R.C (Eds.), Atrocities and international accountability: Beyond transnational justice (pp. 225-245).Tokyo, Japan: United Nations University Press.

Sampson, I. T. (2013). The dilemmas of counter-BokoHaramism: Debating state responses to Boko Haram terrorism in northern Nigeria. Security Journal, 0955-1662, 1-25.

Scharf, M.P. (2007). Trading justice for peace: The contemporary law and policy debate.In Schabas, W.A., Hughes, E., \& Thakur, R.C (Eds.), Atrocities and international accountability: Beyond transnational justice (pp. 246-274 ).Tokyo, Japan: United Nations University Press.

Sederberg, P.C. (1995).Conciliation as counter-terrorist strategy.Journal ofPeace Research, 32(3), 295-312.

Slye, R. C. (2002). Legitimacy of amnesties under international law and general principles of anglo-american law: Is a legitimate amnesty possible. Virginia Journal of International Law, 43(173), 174-248.

Tessier, K. (2009). Reverse order chronology from Jan 2009: Conflict in the Niger Delta Region. In Synge, R (Ed.),Institute of Strategic Studies- Armed Conflict Database, Published by Europa World Plus.

Ubhenin, O.E. (2013). The federal government's amnesty programme in the Niger-Delta: An appraisal. YonetimBilimleriDergisi, 11(21), 179-203.

Waldek, L., Jayasekara. S. (2011). Boko Haram: The evolution of Islamist extremism in Nigeria, in Journal of Policing, Intelligence and Counter Terrorism. Retrieved fromhttp://www.tandfonline.com. 